\title{
Phytochemical and Antimicrobial Studies of Extracts from the Leaves of Tithonia Diversifolia for Pharmaceutical Importance
}

\author{
*John-Dewole, O.O. And Oni, S.O. \\ Department of Biochemistry, Lead City University, Ibadan, Nigeria
}

\begin{abstract}
Phytochemical screening of extracts from the leaves of Tithonia diversifolia displayed the presence of Alkaloids, Saponin, Saponin glycoside, Tannin, Balsam, Cardiac glycoside and Volatile oil. Spectrophotometric analysis for trace metals, Phosphorus and Sulphur showed that T. diversifolia contained Mn $(0.490 \pm 0.001$ $\mathrm{mg} / \mathrm{lo0g}), \quad \mathrm{Zn} \quad(1.609 \pm 0.001 \mathrm{mg} / 100 \mathrm{~g}), \quad \mathrm{Cu}(0.454 \pm 0.001 \mathrm{mg} / \mathrm{log}), \quad \mathrm{Ni}(0.758 \pm 0.001 \mathrm{mg} / 100 \mathrm{~g}), \quad \mathrm{Fe}$ $(0.690+0.002 \mathrm{mg} / \mathrm{l} 00 \mathrm{~g}), P(55.62+0.200 \mathrm{mg} / 100 \mathrm{~g})$ and $S(709+1.000 \mathrm{mg} / 100 \mathrm{~g})$. The medicinal properties of the extract were evaluated in-vitro by antimicrobial and antifungal assays. The aqueous extract (but not methanol and petroleum ether extracts) showed growth inhibitory effects on Staphylococcus aureus and Escherichia coli, but Pseudomonas aeruginosa and Saccharomyces cerevisiae were resistant to all the plant extracts and the antibiotic controls. The Minimum Inhibitory Concentration (MIC) of the aqueous extract of T. diversifolia on S. aureus and E. coli were both 12.50mg. The Minimum Bacterial Concentration (MBC) of the aqueous extract against the test organism ranged from $12.50 \mathrm{mg}$ to $25.00 \mathrm{mg}$.
\end{abstract}

Keywords: antimicrobial, herbal, pharmaceutical, phytochemical, T. diversifolia

\section{Introduction}

The use of plants and plant extracts for medicinal purposes has been going on for thousands of years; and it has been the source of much useful therapy in both herbalism and folk medicine (Bubayero, 1998). The Mexican Sunflower ( $T$. diversifolia) belongs to the plant family known as compositae (Asteraceae). It is an annual broadleaf weed reported to have been introduced into West Africa as an ornamental plant (Akobundu and Agyakwa, 1997) but has become a weed problem in field crops, wasteland and roadsides (Baruah et al., 2000). The plant is about $2.5 \mathrm{~m}$ high, bushy, much branched and perennial. It reproduces from seeds and through vegetative re-growth of the basal stem when the plant is cut. The stem is quadrangular, spirally-ridged, pubescent below and glabrous above. The leaves are simple, alternate, lobed and of about $5-15 \mathrm{~cm}$ long and 3.5$6 \mathrm{~cm}$ broad. It is dark green, toothed and wedged shaped at the base (Akobundu and Agyakwa, 1997). The inflorescence is a solitary capitulum on a peduncle $7-15 \mathrm{~cm}$ long with large orange-yellow florets, while the fruit is compressed and about $6 \mathrm{~mm}$ long.

Not much has been reported about $T$. diversifolia in Nigeria, because it is a relatively new introduction to the Nigerian weed ecology (Bubayero, 1998). Preliminary observation by Akobundu and Agyakwa, (1997) showed that this shrub is an aggressive weed because it grows rapidly, forming large communities and eliminates other plants by forming canopy over them, thus cutting off light supply. However, some research findings reported the activities of T. diversifolia. Tongma et al. (2008) reported the allelopathic activity of the Mexican sunflower in the soil. Aqueous extract of the leaves of this plant applied to soil was shown to inhibit the growth of test plant species. Thus, the extract of the leaves was confirmed to be phytotoxic, and contain some allelochemicals. Baruah et al. (2000) were able to isolate growth inhibitory sesquiterpene lactones and a flavone from $T$. diversifolia. It is interesting to observe that a weed like this plant could also contain a natural pesticide, owing to its pesticidal activity. Schuster et al. (1999) reported the isolation of sesquiterpene lactones from two Tithonia species; Tithonia diversifolia and Tithonia rotundifolia. The sesquiterpene lactones isolated were found to be pesticidal on test plants. Thus, the aim of this study is to investigate the various phytochemical and anti-microbial properties of the leaves of $T$. diversifolia that are available for medicinal, pharmaceutical and agricultural use.

\section{Materials And Methods}

The leaves of $T$. diversifolia were collected along Federal University of Technology, Akure expressway, in Ondo State and along Asa Dam express bye-pass, Ilorin, Kwara State and in Ogbomosho in Oyo State. The plant species was later identified and authenticated by the department of Botany, University of Ilorin, Kwara State. The leaves were dried at $32^{\circ} \pm 2^{\circ} \mathrm{C}$ for two weeks on a clean pavement prior the analysis. The drying process was further enhanced by the harmattan wind. 


\section{Sampling}

The dried bulk samples of the leaves were pulverized using pestle and mortal, and sieved through a $2 \mathrm{~mm}^{2}$ wire mesh to obtain a fine powder. The powdered samples were mixed together and quartered to obtain a representative sample weighing $150 \mathrm{~g}$.

\section{Aqueous Extracts}

$20 \mathrm{~g}$ of powdered leaves of $T$. diversifolia was weighed into $250 \mathrm{ml}$ beaker and $150 \mathrm{ml}$ of distilled water was poured unto the beaker content. The solution was stirred with a glass rod and allowed to soak for $24 \mathrm{~h}$. The aqueous extract was filtered thrice through a plug of absorbent cotton-wool in a glass funnel. The aqueous extract was then filtered through $11 \mathrm{~cm}$ Rundfilter paper MN713. The solution was concentrated by gentle evaporation on a heating mantle and poured into a $100 \mathrm{ml}$ beaker.

\section{Methanolic Extracts}

$200 \mathrm{ml}$ of methanol was measured into the round-bottom flask of the soxhlet. $20 \mathrm{~g}$ of the powdered leaves was placed in the sample container (i.e. thimble) of the soxhlet. The apparatus was coupled and the system was switched on at thermostat temperature of $65^{\circ} \mathrm{C}$. The sample was continuously extracted under reflux for $3 \mathrm{~h}$, and the extract was poured into $100 \mathrm{ml}$ flask. Methanolic extract of the sample was concentrated by gentle evaporation on a heating mantle.

\section{Petroleum Ether Extracts}

$200 \mathrm{ml}$ of petroleum ether was measured into the round-bottom flask of the soxhlet. $20 \mathrm{~g}$ of the powdered leaves of $T$. diversifolia was placed in the thimble of the soxhlet. The apparatus was coupled and the system was switched on at thermostat temperature of $60^{\circ} \mathrm{C}$. The sample was continuously extracted under reflux for $3 \mathrm{~h}$ and the extract was poured into $100 \mathrm{ml}$ beaker after some of the petroleum ether had been recovered. The $100 \mathrm{ml}$ extract of the sample was concentrated by gentle evaporation on a heating mantle.

\section{Phytochemical Screening of Crude Extracts}

Phytochemical screening of the crude extract for saponin, saponin glycoside, tannin, anthracene, alkaloid, volatile oil, balsam and cardiac glycoside were carried out by the methods described by Evans (1999), Harbone (1993) and Sofowora (1999).

\section{Spectroscopic Analysis of Crude Extracts}

Methods of Howtz (1990), Skoog et al. (2006) and Pavial et al. (1992) were used for spectroscopic analysis of the samples, using Atomic Absorption Spectrophotometer (A200).

Colorimetric determination of Phosphorus was done using Vanadomolybdate (Yellow) method (AOAC, 2000). Spectrophotometric determination of Sulphate was done using Turbidometric method (AOAC, 2000). Antimicrobial assay of crude extracts of T. diversifolia was done using the methods described by Egwari (1999), Ntiejumokwu and Kolawole (1990), and WHO (1991) to test the effects of crude extracts on the following pathogenic microorganisms: Staphylococcus aureus, Pseudomonas aeruginosa, Escherichia coli and Saccharomyces cerevisiae. Determination of antibiotic activity and antibiotic control was done by using the Disc Diffusion and Agar Diffusion techniques as described by WHO (1991). Determination of Minimum Inhibitory Concentration (MIC) of the crude extracts was done by using Tube Dilution method as described by Rotimi et al. (1999).

\section{Results}

Table 1 gives the phytochemical compounds present in crude extract of the leaves of $T$. diversifolia. The extracts were positive for some of the following compounds; alkaloids, anthracene, balsam, cardiac glycoside, saponin, saponin glycoside, tannin and volatile oil indicating their presence in the extract.

Table 1: Phytochemical Compounds in leaves of T. diversifolia

\begin{tabular}{ll}
\hline Phytochemical Compounds & Remarks \\
\hline Alkaloids & $+\mathrm{ve}$ \\
Anthracene & $-\mathrm{ve}$ \\
Balsam & $+\mathrm{ve}$ \\
Cardiac glycoside & $-\mathrm{ve}$ \\
Saponin & $+\mathrm{ve}$ \\
Saponin glycoside & $+\mathrm{ve}$ \\
Tannin & $++\mathrm{ve}$ \\
Volatile oil & $+\mathrm{ve}$ \\
Key: ++ ve = strongly positive, $+\mathrm{ve}=$ positive,, -ve = negative
\end{tabular}


Table 2 shows the trace metal contents of the plant extract in $\mathrm{mg} / 100 \mathrm{~g}$. The plant samples contained Manganese, Zinc, Copper, Nickel and Iron, while Table 3 shows the concentration of Phosphorus and Sulphur content of the extract in $\mathrm{mg} / 100 \mathrm{~g}$.

Table 2: Trace Metals content in $\mathbf{m g} / \mathbf{1 0 0 g}$

\begin{tabular}{ll}
\hline Elements & Conc. $(\mathbf{m g} / \mathbf{1 0 0 g})$ \\
\hline Manganese & $0.490 \pm 0.001$ \\
Zinc & $1.609 \pm 0.001$ \\
Copper & $0.454 \pm 0.001$ \\
Cobalt & ND \\
Cadmium & ND \\
Nickel & $0.758 \pm 0.001$ \\
Iron & $1.690 \pm 0.002$ \\
Lead & $0.031 \pm 0.002$ \\
\hline
\end{tabular}

The value represents mean $\pm \mathrm{SD}(\mathrm{N}=3), \mathrm{ND}=$ Not Detectable

Table 3: Phosphorus and Sulphur concentration of the extract

\begin{tabular}{ll}
\hline Elements & Conc. $(\mathbf{m g} / \mathbf{1 0 0 g})$ \\
\hline Phosphorous & $55.62 \pm 0.200$ \\
Sulphur & $709.00 \pm 1.000$ \\
\hline
\end{tabular}

The value represents mean $+\mathrm{SD}(\mathrm{N}=3)$

Table 4 gives the inhibitory effects of extract of $T$. diversifolia leaves at $15 \mathrm{mg}$. Staphylococcus aureus and Escherichia coli were sensitive to aqueous extract of $T$. diversifolia with zone diameters of inhibition of $6 \mathrm{~mm}$ and $10 \mathrm{~mm}$ respectively. However, Pseudomonas aeruginosa and Saccharomyces cerevisiae (a fungus) were resistant (i.e. shows no growth inhibition) to extract of $T$. diversifolia and the antibiotic controls. Staphylococcus aureus and Escherichia coli were sensitive to the antibacterial effects of Tetracycline hydrochloride (15mg) and Ampicillin trihydrate $(15 \mathrm{mg})$ which were used as positive controls, with zone diameter of inhibition of $22 \mathrm{~mm}$ and $26 \mathrm{~mm}$ respectively (for ampicillin) and $26 \mathrm{~mm}$ and $27 \mathrm{~mm}$ respectively (for tetracycline). Table 5 and 6 show the Minimum Inhibitory Concentrations (MIC) of the extracts on pathogens; the MIC of extracts of T. diversifolia on both Staphylococcus aureus and Escherichia coli was 12.50mg.

Table 4: Inhibitory Effects of Extracts of Leaves of T. diversifolia (15mg)

Zone diameter $(\mathbf{m m})$ of growth inhibition

\begin{tabular}{llllll}
\hline Pathogens & Aqueous & Methanol & $\begin{array}{l}\text { Pet. } \\
\text { Ether }\end{array}$ & $\begin{array}{l}\text { Ampicillin } \\
\text { Control }\end{array}$ & $\begin{array}{l}\text { Tetracycline } \\
\text { Control }\end{array}$ \\
\hline $\begin{array}{l}\text { Staphylococcus aureus } \\
\text { Pseudomonas }\end{array}$ & 6 & 0 & 0 & 22 & 26 \\
$\begin{array}{l}\text { aeruginosa } \\
\begin{array}{l}\text { Escherichia coli } \\
\text { Saccharomyces }\end{array}\end{array}$ & 0 & 0 & 0 & 0 & 0 \\
cerevisiae & & 0 & 0 & 26 & 27 \\
\hline
\end{tabular}

Table 5: The MIC of T. diversifolia on Staphylococcus aureus

\begin{tabular}{llll}
\hline Extract & Concentration $(\mathbf{m g} / \mathbf{1 0 0 g})$ & Growth Indication & MIC $(\mathbf{m g} / \mathbf{1 0 0 g})$ \\
\hline A1 & 25.00 & Nil & \\
A2 & 12.50 & Nil & 12.50 \\
A3 & 6.25 & + & \\
A4 & 3.13 & + & \\
A5 & 1.56 & + & \\
\hline
\end{tabular}

Key: A = Aqueous extract

$+=$ Positive growth

Nil $=$ No growth 
Table 6: The MIC of T. diversifolia on Esherichia coli

\begin{tabular}{llll}
\hline Extract & Concentration $(\mathbf{m g} / \mathbf{1 0 0 g})$ & Growth Indication & MIC (mg/100g \\
\hline A1 & 25.00 & Nil & \\
A2 & 12.50 & Nil & 12.50 \\
A3 & 6.25 & + & \\
A4 & 3.13 & + & \\
A5 & 1.56 & + & \\
\hline
\end{tabular}

Key: $\mathrm{A}=$ Aqueous extract

$+=$ Positive growth

Nil $=$ No growth

\section{Discussion}

The study showed (Table 1) that the leaves of $T$. diversifolia contained Saponin, Alkaloids, Saponin glycoside, Tannin and Balsam. This result agrees with similar research done by Kela et al. (1999); Menut et al. (2002) and Okogun (1996). These phytochemical compounds have pharmacological effects and have been the basis of chemical synthesis of drugs used in modern medicine responsible for their medicinal use in traditional medicine (Sofowora, 2001) and (Okogun, 1996). Saponins are found in most plants as nitrogen-free glycosides, each consisting of a sapogenin and a sugar molecule. Glycosides are large and varied groups of naturally occurring plant products, characterized, on hydrolysis, by the formation of sugar and non-sugar moiety. Schuster et al. (1999) and Egwari (1999) have isolated steroidal glycosides such as Hecogenin, Progesterone, Testerone and Diosgenin from plants and are now being used therapeutically as hormones and contraceptives in medicine. Cardiac glycosides, digitoxin and digoxigenin have varying effects in the cardiovascular systems of human. They are used in the treatment of heart disorders and high blood pressure (Groth, 1994 and Stenlake, 1997). Tannins are polyphenolic compounds also used for medicinal purposes e.g. catechol, hydroquinine and resorcinol are phenolic salicylates used as analgesics, antipyretics and as internal antiseptics in medicine and surgery (Bello, 1999 and Stenlake, 1997). Tona et al. (2008) showed that $T$. diversifolia contain sesquiterpenes lactones and Tagitinin with pesticidal activity, anti-amoebic activity and antibacterial effect. Therefore, the antimicrobial effect of crude extract of $T$. diversifolia on the growth of pure isolates of Staphylococcus aureus and Escherichia coli may be attributed to these compounds. Thus, the presence of these phytochemicals in $T$. diversifoila could be responsible for the observed pharmacological effects and their medicinal use in traditional medicine. Analysis of trace metals (Table 2) showed that $T$. diversifolia contains $\mathrm{Mn}, \mathrm{Zn}, \mathrm{Cu}, \mathrm{Ni}, \mathrm{Fe}$ and $\mathrm{Pb}$. The concentrations (mg/100g) of Fe and $\mathrm{Zn}$ (Table 3) are very high, which suggests the presence of some bioorganic compounds. In the contrast the concentration of $\mathrm{Pb}$ is the lowest and therefore in the permissible level of consumption of the leave decoction. The high concentration of sulphur could be responsible for the antimicrobial (medicinal) properties, since sulphur-containing compounds are known for their antibiotic effects (Stenlake, 1997). For instance, the clinical effectiveness of sulphanimides in the control of bacterial infection has led to their use against pneumonia and streptococci infections (Tona et al., 2008). Groth (1994) and Stenlake (1997) remarked that mere isolation and structural elucidation $\mathrm{f}$ plant extract may not be too significant, until appropriate bioassays are carried out to establish the biological activity exhibited by plant extracts. Therefore, microbiological screening of the crude extracts of $T$. diversifolia was carried out to establish its antimicrobial effects on pure isolates of pathogenic bacteria and fungi consisting of $S$. aureus, P. aeruginosa, E. coli and $S$. cerevisiae. The study showed that aqueous extracts of $T$. diversifolia possesses antimicrobial effect against the growth of pure isolate of $S$. aureus and E. coli. These findings are similar to that reported by Egwari (1999) and Rotimi et al. (1999). The result of zone diameters of inhibition of the plant extract on the growth of Staphylococcus aureus and Escherichia coli (Table 4) compared favourably with that of standard antibiotic controls consisting of Tetracycline hydrochloride (15mg) and Ampicillin trihydrate (15mg) (WHO, 1991 and Cheesebrough, 2000). Pseudomonas aeruginosa was resistant to all the plant extract and antibiotic controls. This observation agrees with that of Timothy and Nelson (1992) and Cheesebrough (2000). The plant extract had no antifungal activity against Saccharomyces cerevisiae. The Minimum Inhibitory Concentration (MIC), which is the concentration that permitted no visible growth after $24 \mathrm{~h}$ of incubator; was found to range from $1.56 \mathrm{mg}$ to $6.25 \mathrm{mg}$ for all the plant extracts (Table $5 \& 6$ ). The Minimum Bactericidal Concentration (MBC) of the plant extracts against the test organisms ranged from $12.50 \mathrm{mg}$ to $25.00 \mathrm{mg}$. Therefore, the industrial utilization of the extracts of $T$. diversifolia as raw material for pharmaceutical industry has high prospect because of its antibacterial activity, availability, solubility and percentage yield.

\section{Conclusion}

The phytochemical screening of the crude extract of $T$. diversifolia tested positive for the presence of Saponin, Alkaloids, Saponin glycoside, Tannin and Balsam. The concentration (mean+SD) of elements analysed in $\mathrm{mg} / 100 \mathrm{~g}$ exhibited $\mathrm{S}>\mathrm{P}>\mathrm{Fe}>\mathrm{Zn}>\mathrm{Ni}>\mathrm{Mn}>\mathrm{Cu}>\mathrm{Pb}$. The high concentrations of sulphur and phosphorus 
signified an index for the plant's medicinal properties. The medicinal properties of the plant as evaluated invitro by antimicrobial assay revealed that aqueous extract showed growth inhibitory effects on Staphylococcus aureus and Escherichia coli. However, Pseudomonas aeruginosa was resistant to the plant extract and antibiotic controls. The plant extracts have no antifungal effects on Saccharomyces cerevisiae.

\section{Recommendations}

Further work is recommended on isolation and characterization of active chemical compounds responsible for the antimicrobial/antibacterial properties of the plant. Medicinal plants are known to exhibit seasonal variation in chemical properties and bioactivity, which could also affect their medicinal properties at any given period of time. Therefore, there should be an investigation to mitigate the seasonal variation in chemical properties of this plant.

\section{References}

[1]. Akobundu I.O. and Agyakwa C.W. (1997): A Handbook of West African Weeds. International Institute of Tropical Agriculture (I.I.T.A.) Ibadan, Nigeria, 18, $76-79$.

[2]. AOAC, (2000): Official Methods of Analysis, 12th Ed. Association of Official Analytical Chemist. Washington, D.C. 112 - 117.

[3]. Baruah, N.L., Sarma J.C., Barua, N.C., Sarma, S. and Sharama R.P. (2000): Germination and Growth Inhibitory of Sesquiterpene Lactones and a Flavone from T. diversifolia. Phytochemistry, 36 (1): $29-36$.

[4]. Bello, M.K. (1999): Detection of Phenolic acid derivatives from Plum Tree. Journal of Plant Science, vol. 15, pp 334 - 340.

[5]. Bubayero, A.M. (1998): Traditional Medicine in the Service of Man. Medicinal Plant Research in Nigeria, $12,129-142$.

[6]. Cheesebrough, M. (2000): District Laboratory Practice in Tropical African Countries. Vol 2. Cambridge University Press pp. 157 159.

[7]. Egwari L.O. (1999): Antibacterial Activity of Crude Extract of Nauclea latifolia and Eugenia aromatica. West African Journal of Drug Research. 15 (1\&2): 55 - 59.

[8]. Evans, C.W. (1999): Trease and Evans Pharmacognosy. $15^{\text {th }}$ Edition. Bailliere Tindall Press, pp. 245 - 263.

[9]. Groth, A. (1994): Medicinal Pharmacology. $10^{\text {th }}$ edition. C.V. Mosby pp $300-302$.

[10]. Harbone, J.B. (1993): Phytochemical Methods; a Guide to Modern Techniques of Plant Analysis. $5^{\text {th }}$ Ed. Prentice and Hall. pp.68 80 .

[11]. Howtz, K. (1990): Official Methods of Analysis $12^{\text {th }}$ edition, by Association of Official Analytical Chemist.

[12]. Kela, S.L. , Ogunsusi, R.A., Ogbogo, V.C., and Nwude, N. (1999): Screening of some Nigerian Plants for Molluscidal Activity. Revaed' Elevage et Demedicine Veterinaire des Pays Tropicaux (France) 44 (1) 195 - 202.

[13]. Menut, C., Lamaty, G., Amvam-zello, P., Kuiate, J.R. and Bessiere, J.M. (2002): Chemical Composition of Flower's Essential Oils of Tithonia diversifolia from Cameroon. Journal of Essential Oil Research. 4 (6): 651 - 653.

[14]. Ntiejumokwu, S. and Kolawole, J.O. (1990): An Antimicrobial and Preliminary Screening of the back of Nauclea latifolia. West African Journal of Phamarcology and Drug Research. 9: 87 - 91

[15]. Okogun, J.I. (1996): The Chemistry of Nigerian Medicinal Plants. Medicinal Plant Research in Nigeria. 10.31 - 45.

[16]. Pavial, L.D., Lampman, M.G., and Kriz, G.S. (1992): Organic Laboratory Technique. $2^{\text {nd }}$ edition. Saunders Press, USA) pp 553 585.

[17]. Rotimi, V.O., Mosadomi, H.A., and Sogaolu, O.G. (1999): The Inhibitory Action of Aqueous Extracts of some African Chewing Sticks on Streptococcus mitus; Implication in Dental Caries. West African Journal of Medicine. (11): $234-239$.

[18]. Schuster, A., Stokes, S., Papastergious, F., Castro, V., Poveda, L., and Jakupovic, J. (1999): Sesquiterpene Lactones from two Tithonia spp. J. Phytochemistry. 31 (9): $3139-3141$.

[19]. Skoog, D.A., West, D.M., and Holler, H.J. (2006): Fundamentals of Analytical Chemistry. $7^{\text {th }}$ edition. Saunders Press, USA. pp 86 96.

[20]. Sofowora, A. (1999): African Medicinal Plants. Medicinal Plant Research in Nigeria. 13. 455 - 462.

[21]. Sofowora, A. (2001): Medicinal Plants and Traditional Medicine in Africa. J. Phytochemistry. 34 (8): 223 - 230

[22]. Stenlake, J.B. (1997): Medicinal and Pharmaceutical Chemistry. $2^{\text {nd }}$ edition. Altone Press London. pp. 40 - 42.

[23]. Timothy, K. and Nelson, F.F. (1992): Antibacterial Activities of Crude Extract of Aspergillus quadrillineatus Isolated from a Nigerian Cereal. African Journal of Pharmaceutical Science. 22 (2): 101 - 106.

[24]. Tona, L., Kanbu, K., Nigimbi, N., Cimanga, K., and Vietinck, A.J. (2008): Anti-amoebic and Phytochemical Screening of Some Congolese Medicinal Plants. Journal of Ethnopharmacology. 61 (1): 57 - 65.

[25]. Tongma, S., Koboyashi, K. and Usui, K. (2008): Allelopathic Activity of Mexican Sunflower (Tithonia diversifolia) in soil. Journal of Weed Science (USA). 46 (4): 432 - 437.

[26]. WHO (1991): Basic Procedures in Clinical Bacteriology. WHO Geneva pp. 62 - 71. 